\title{
Open Access for Social Work Research and Practice
}

\author{
Elizabeth A. Bowen \\ Mark A. Mattaini \\ Sandra L. De Groote \\ University of Illinois at Chicago
}

\begin{abstract}
Open access publishing is increasing across many fields as a means of facilitating timely and equitable access to knowledge. To examine the extent of open access in social work serials publishing, we gathered information on the subscription costs and access policies of 81 peerreviewed social work journals. Although some trends toward increased access are noted, such as publishers' acceptance of university archiving policies, the majority of journals provided no or minimal open access. Average annual subscription prices based on 2011 data were $\$ 126$ for individuals and $\$ 579$ for institutions for print and online access. Our review located 11 social work journals that are fully open access. In light of these findings, we review the importance of open access for facilitating social work research and evidence-based practice, and describe possible steps toward expanding access in the context of conflicts between the increasing corporatization of publishing and the growing recognition of knowledge as a common good. From this perspective, research findings should be broadly available regardless of socio-economic advantage or development status. Much of this research has been supported through public funding, and knowledge important to human social welfare should not be withheld as proprietary.
\end{abstract}

\section{Keywords: evidence-based practice, journal publication, open access, social work ethics}

Social work has widely embraced the evidencebased paradigm as an essential framework for practice, including clinical, management, and policy practice arenas. Social work scholarship exists primarily to support those professional functions. Much more than practice guidelines or manualized interventions, at its core evidence-based practice is both a philosophy and a process that demands practitioners consider the best available knowledge when making decisions (Gambrill, 2006; Marsh, 2012). This paradigm has diffused across a diverse range of practice settings with individuals, groups, organizations, and communities (Rzepnicki, McCracken, \& Briggs, 2012). As Thyer (2008) noted, "evidence-based practice involves having all of us, students, practitioners, and researchers alike, learning to ask answerable questions related to assessment and intervention; learning to find the best available evidence and to critically appraise it..." (p. 344; emphasis added).

Access to "the best available evidence" is just one dimension of the evidence-based process, but it is central. The digitization of knowledge and Internet access have made research findings and other types of knowledge more accessible to more people than ever before (Howard, McMillen, \& Pollio, 2003), expanding the potential for evidence-based work, but such access is far from universal. Graduates trained in evidence-based practice in schools of social work often become discouraged when trying to access current research in agency settings, given the high price of academic journals (including for single articles, as discussed later) as well as other factors such as limited time and agency support (Berger, 2010; Holden, Barker, Rosenberg, \& Cohen, 2012; Rzepnicki et al., 2012). Social work research advances most rapidly under conditions of timely access to others' research findings and to work being done in other settings, cultures, and countries; a particularly important consideration as social work becomes increasingly international. Scholars in disadvantaged countries and poorer institutions cannot teach or build on advances that they do not know about and indigenous research done in developing countries remains largely unknown to those in the developed world, which potentially limits the diversity of information available to the profession as a whole (Ahmed, 2007; Yu, 2006).

We therefore argue that current limitations on access to the best available knowledge have serious practice, research, and ethical implications. We begin with an overview of the contemporary expansion of open access across multiple disciplines, describing changes in publishing practices that have precipitated the call for open access, forms that open access can take, and payment models used to fund open access publishing. Next, we assess the extent of open access in social work serials publishing by evaluating access levels in 81 peer-reviewed social work-related journals. We conclude with a discussion of the importance of open access for the social work profession, and review actions that scholars, practitioners, universities, 
and publishers could take to advance the movement toward open access in social work publishing. While recognizing the importance of the multiple mechanisms through which access can be increased, we highlight in particular the role of fully open access journals, in which all journal content is freely available online to all users.

\section{Open Access: Context, Forms, and Costs}

The Internet has undoubtedly expanded opportunities for the dissemination of research. For example, most journals now provide free online access to article abstracts, often months in advance of publication. At the same time, the corporatization of serials publishing and the escalation of journal subscription costs have constrained access. In response to these trends, a growing movement for more open access has emerged across disciplines. Laakso and colleagues (2011) found that the number of fully open access journals (one form of open access) is growing at a rate of $18 \%$ a year (and publication of articles in them at a rate of $30 \%$ ), as compared with an increase of $3.5 \%$ for journal publication in general.

Researchers are being encouraged to publish articles in open access journals and to make articles accessible through institutional repositories (Create Change, 2012). Several universities, including Harvard University and Massachusetts Institute of Technology as well as public institutions such as the University of Kansas and Georgia Institute of Technology, have adopted broad open access policies requiring faculty to deposit their publications in open access institutional repositories unless a faculty member opts out of the policy for a particular article through the use of a waiver (Harvard University, 2010). Further, the National Institutes of Health (NIH) require that articles stemming from NIH grant-funded research and published in peer-reviewed journals be made publicly available through PubMed Central within one year of publication (NIH, 2008). Overall, the open access movement views knowledge as a commonly held resource rather than as a commodity available only to those who can afford it (Willinsky, 2006).

The publication of open access articles has grown in all disciplines, although biomedicine has seen the greatest growth, increasing from 7,400 articles in 2000 to 120,900 in 2011 (Laakso \& Björk, 2012). In 2011, about $12 \%$ of the articles indexed in the Scopus scholarship database were available through an open access journal (Laakso \& Björk, 2012). Many fully open access journals have impact factors ranking them among the highest in their field, particularly in science. For example, Molecular Systems Biology ranks 24th out of 290 journals in its field according to the 2011 Thomson Reuters Journal Citation Reports (JCR;
2012). PloS Biology and BMC Biology rank first and sixth respectively out of 85 biology journals. As early as 2001, in computer science and related disciplines, more than $85 \%$ of the most-cited articles appeared in open access journals, a rate that has no doubt accelerated (Lawrence, 2001).

Not all disciplines have yet produced high impact open access journals. The limited amount of open access literature in fields outside of biomedical sciences suggests that most community practitioners might be limited in their ability to access high-quality literature to support evidence-based practice and policy. For example, a 2006 study of workers in a state public health department found that these professionals needed "improved access to grey literature as well as to more systematic reviews, summaries, and fulltext articles" (LaPelle, Luckmann, Simpson, \& Martin, 2006, p. 7). Further, a study at an Ontario, Canada public health department noted that the ability to make evidence-based decisions required not only training, technological resources, and a receptive organizational culture but also the ability to access research (Peirson, Ciliska, Dobbins, \& Mowat, 2012). However, an experimental study demonstrated that mental health practitioners were significantly more likely to read an article with relevant practice information when given a citation to an open access article rather than a citation for a paid access article or no citation (Hardisty \& Haaga, 2008). To the extent that social work moves toward a scientific base, the same supports are needed (Rzepnicki et al., 2012).

\section{Technological and Economic Context for Open Access}

Although peer-reviewed academic journals have appeared in print for more than 300 years, technological advances of the past few decades have created new possibilities in online publishing (Solomon, 2008). Björk, Roosr, and Lauri (2008) estimated that 23,750 academic journals published approximately 1,350,000 articles in 2006, many of which were available exclusively online. However, as the number of peerreviewed journals has increased, so have institutional subscription costs, particularly for many prominent journals that libraries view as essential to their collections (Solomon, 2008). Between 1986 and 2006, journal prices increased an average of $180 \%$ whereas the U.S. Consumer Price Index rose by only $84 \%$ (Association of Research Libraries, 2008). These price increases have reduced library budgets for books and other media. The average annual institutional subscription cost for scientific journals in the United States is now $\$ 2,648$, with prices for some titles far higher (Bosch, Henderson, \& Klusendorf, 2011). For example, though tiered pricing schemes dictate that 
different types of institutions pay different rates, universities with medical schools paid \$7,350 for a 2011 subscription to the New England Journal of Medicine (Bosch et al., 2011). Public libraries and community colleges were charged $\$ 1,260$.

Rising subscription costs are due in part to the trend toward corporatization in scientific publishing. At the end of 2006, approximately $60 \%$ of the scholarship indexed in the ISI Web of Science was published in journals owned or published by one of the three largest corporate publishers: Reed Elsevier, Springer, and Taylor \& Francis (Willinsky, 2006). Scherlen and Robinson (2008) pointed out that the 2007 merger of John Wiley with Blackwell Publishing, creating Wiley-Blackwell, should be added to these ranks. Many titles previously published through progressive small presses have been acquired by large corporations, usually resulting in higher subscription costs for individuals and institutions. For example, several social work-related journals previously published by Haworth Press, including the Journal of Gay \& Lesbian Social Services and Journal of Progressive Human Services, were acquired by Taylor \& Francis in 2007. In other cases, professional associations have partnered with corporate or university publishers. In 2012, publication of the National Association of Social Workers' (NASW) journals shifted to Oxford University Press, and the Council on Social Work Education's (CSWE) Journal of Social Work Education has been published by Taylor \& Francis since January 2013.

Concurrent with rising institutional subscription rates, many libraries are experiencing budget cuts, particularly at public universities where state budget crises have placed higher education spending under intense scrutiny (Bosch et al., 2011). These economic conditions, coupled with the growing number of scholarly journals, mean that libraries must make difficult choices about their serials collections. Social work journals are in direct competition with other health and social science journals (and ultimately with those in the sciences and humanities as well) for dwindling serials budgets.

The confluence of increased opportunities for dissemination of research findings through online journals with cost barriers limiting access to this research has fostered the call for open access. In 2001, the nonprofit Open Society Institute convened scholars from multiple disciplines to establish the Budapest Open Access Initiative, calling for universal free access to scientific and scholarly literature. The initiative defined open access literature as:

...free availability on the public internet, permitting any users to read, download, copy, distribute, print, search, or link to the full texts of these articles, crawl them for indexing, pass them as data to software, or use them for any other lawful purpose, without financial, legal, or technical barriers other than those inseparable from gaining access to the internet itself. (Open Society Institute, 2002)

The online Directory of Open Access Journals (DOAJ) uses this definition to establish its criteria for indexing scholarly journals that make their content freely available to all users (though not necessarily free to authors, as discussed below). Currently the DOAJ database includes more than 8,000 journals from around the world, representing a variety of subjects.

\section{Forms of Open Access}

Although the Budapest definition represents a gold standard for access (referred to as full open access in this article), many publications operate using hybrid models that incorporate open access in more limited ways. Partial models generally enable access in one of three ways: (a) making some articles available free of charge but charging a fee for others; (b) making content free for some categories of users but not for all users; or (c) adopting archiving and/or copyrighting policies that enable authors to share work through other outlets. An example of the first approach is providing open access to older articles, but charging for access to content in current journal issues (Solomon, 2008). Another example is offering an open choice option, allowing authors to designate their article as fully open access in exchange for a fee. In this case, a reader will be required to pay for all content except those articles for which the authors have paid an open choice fee.

The second open access model is typically achieved by allowing free access for scholars in developing countries or users from certain types of institutions, while requiring all others to either subscribe or pay for access to specific articles. An example of this model is the World Health Organization's (WHO) Health Inter-Network for Access to Research Initiative (HINARI). Through HINARI, content from participating journals is made freely available to educational and research institutions in more than 70 low-income countries; in addition, lowcost bundled subscriptions are available to institutions in 28 middle-income nations (WHO, 2012).

The third approach, archiving, enables scholars to make their manuscripts available in personal, institutional, or public archives, in addition to the journals that publish their work. Although archiving policies vary considerably among publishers, more than $90 \%$ 
of publishers permit authors some form of selfarchiving (Scherlen \& Robinson, 2008). Publishing in an institutional archive or public archive such as the NIH's PubMed Central offers advantages such as providing persistent URL addresses for articles and indexing services. Another important facet of publishing that affects access is the management of copyrights. Traditionally, publishers have held copyrights for the articles published in their journals. Recently, some journals have facilitated access by granting authors limited licenses to share their work under certain conditions; for example, allowing authors to freely distribute their work as long as it is properly attributed and used for noncommercial purposes (Solomon, 2008). However, open access is not synonymous with author-held copyrights. A fully open access journal that makes all of its content freely available online may retain the copyright to articles; conversely, journals that share copyrights with authors may still charge for content.

\section{Financing Open Access}

While fully open access journals are free to access and read, similar to traditional journals they are not free to produce. Fully open access journals require the same quality control and peer-review processes as traditional journals, and use multiple models for covering their production costs. One model, referred to as the author-pay model, requires authors to pay article processing fees to have the article published (Doyle, Gass, \& Kennison, 2004). Open access publishers such as Public Library of Science and BioMed Central use this model. Author fees can range from small amounts to over $\$ 3,000$ (University of California Berkeley, 2012).

In fields not well funded or with limited federal grant opportunities, charging significant author fees can be unrealistic. Some publishers recognize that these fees can strongly influence authors' decisions to publish their papers, and therefore offer a full or partial waiver to those unable to pay the author fees (Doyle et al., 2004). Many educational institutions have begun providing financial support to subsidize author fees for open access publishing. For example, the University of Oregon, Southern Illinois University-Carbondale, Concordia University, and at least 20 others have established funds to reimburse faculty, staff, and students for author fees charged by open access journals (Scholarly Publishing and Academic Resources Coalition [SPARC], 2012a).

Although most author fees are legitimate, predatory open access publishers do exist, particularly in the science, technology, and medical fields (Beall, 2012). These publishers charge author fees mainly for the purpose of profit while employing lax or nonexist- ent review processes, essentially providing those who can pay the ticket price with an easy route to acceptance and publication. We are not aware of major issues of this kind in social work publishing at present, but it is certainly an area to watch.

Alternatively, some fully open access journals obtain support through the allocation of a portion of the membership dues charged by professional associations (Crow, 2009). Others may gain support through advertising, sponsorship, grants, donations from individuals or institutions, and endowments. In addition, many journals have a large volunteer base or rely on in-kind support to manage and publish the journal, including the editorial labor. In-kind support might include student labor, faculty time, administrative support, and hosting services (Crow, 2009). Journal publishing software programs can manage a journal through the various publishing stages including author submission, peer review, copyediting, and publishing the final manuscript. At several academic institutions, university libraries support open access publishing by providing the infrastructure to host open access journals. The rationale for such support is that - in the long run-support for open access can reduce library costs; for this reason university librarians and administrators are among the strongest advocates for expanded access (SPARC, 2012b).

\section{Extent of Open Access in the Social Work Serials Literature}

Until now, little has been known about the extent of open access specifically with regard to social work serials publishing. To explore this issue, we gathered data on subscription costs and access policies for a list of social work-related journals, and used this information to make a determination on each title's access level.

\section{Method}

To begin our examination, a list of peer-reviewed social work-related journals was compiled. This was not a clear-cut task, given the interdisciplinary nature of social work and the breadth of topics and areas of specialization subsumed by the field. Our approach to selecting the sample was to purposefully cast a broad net, recognizing that many social workers read and publish in journals beyond disciplinary mainstays such as NASW's four journals.

We began by reviewing the core list of more than 150 journals indexed in Social Work Abstracts (SWA), produced by NASW (although the full SWA database contains many more titles, we used the core journal list available in the database guide). We selected journals from this list for inclusion based on the following criteria: (a) journals containing "social 
work" in the title; (b) journals containing "social service," "human service," or "social welfare" in the title (e.g., Journal of Social Service Research and Journal of Progressive Human Services); (c) journals that did not meet either of the first two criteria but were published by or affiliated with a social work institution (e.g. NASW's Children \& Schools); and (d) journals that did not meet any of the first three criteria but focused on child abuse or child welfare, given the strong historical and contemporary associations between social work and the child welfare field. These criteria produced a list of 49 titles, with 37 meeting the first criterion, six meeting the second, and three meeting the third and the fourth criteria.

Next, we reviewed the 41 journals indexed under "social work" in the 2011 JCR (JCR, 2012). Although many of the titles overlapped with the SWA list, we identified eight titles meeting one of the above criteria that were not indexed in SWA. Following this step, we added 21 journals that we were aware of that were not indexed in SWA or JCR, but met the inclusion criteria (e.g., School Social Work Journal and Journal of Gay and Lesbian Social Services). Last, we added three journals that did not meet any of the inclusion criteria but that are highly utilized publishing venues for social work authors and have a strong social work presence on their editorial boards. These were Journal of Human Behavior in the Social Environment (a journal developed to support the course content on human behavior in the social environment required by CSWE standards), Child \& Youth Services, and Children and Youth Services Review. The former two are indexed in SWA, while the latter is indexed in both SWA and JCR.

The resulting final list for our analyses contained 81 titles (Appendix A). Bilingual journals published in English and another language were included. While recognizing that there is not widespread consensus on what defines a "social work" journal, the final list represents our best attempt at constituting a broad base from which to examine levels of access in the literature as it is relevant to social workers as researchers, practitioners, authors, and readers alike.

To understand the economic context of social work journal access and to explore which forms of open access were present in the literature, the first author gathered information on key characteristics of each journal. To examine the economic context, including potential variations according to publisher type, we collected data on the journals' subscription options, pricing, and publishers. Because open access can be facilitated at different levels through a number of mechanisms (as described above), we gathered data on several mechanisms, including open-choice options, policies permitting self-archiving, policies facilitating free access in developing countries, and free online availability of journal content. Additional information was gathered for the fully open access journals, including publication frequency, indexing in major outlets (EBSCOhost database network, PsycINFO, SWA), JCR impact factors, and financing models.

This information was obtained primarily from journals' official websites, which, in almost all cases, were maintained by publishers. When information was not readily available on a journal's website, the first author contacted the publisher or editor by e-mail or telephone. Information for a few titles was not obtained even after several contact attempts, resulting in a sample size lower than 81 for some of the analyses. Archiving policies were also checked for each title by the third author on Sherpa-Romeo, a Webbased service that includes information on publishers' copyright and archiving policies. The provision of open access in developing countries was checked by consulting the list of journals participating in the HINARI project to promote access to health-related scientific knowledge in developing countries (WHO, 2012). Indexing of the fully open access journals was checked in the Ulrichsweb electronic database of periodicals, as well as by looking up the titles directly in the PsycINFO and SWA databases.

\section{Analyses}

After gathering data, we classified each journal's publisher into one of three mutually exclusive categories: corporation, university, or professional organization. Corporate publishers consisted of for-profit publishing companies of varying sizes. University publishers consisted of university presses and journals published directly by university departments and libraries. A publisher was classified as a professional organization if the organization published its own journal, such as the Child Welfare League of America's Child Welfare. Journals published by presses affiliated with professional organizations were also included in this category. Several journals published by a corporate press but affiliated with a professional organization were classified as corporate.

We also coded the open-choice options and archiving policies of the journals. Open choice was coded dichotomously, according to whether the journal had a written policy of allowing authors to make their articles freely available to the public in exchange for a fee paid by the author or his or her sponsoring institution. If a journal was classified as having an open-choice option, the amount of the fee was recorded. Similarly, archiving policies were coded dichotomously to indicate whether the journal had a 
written policy allowing authors to archive a version of the article in an institutional or personal repository. If an embargo period was required before the article could be made publicly available free of charge, the length of the embargo was recorded.

Based on the information collected, a determination was made as to the level of open access for each journal. Journals were classified into three categories. Fully open access journals were those that made all of their content available to the public free of costs (i.e., all journal content was available online without any type of subscription or access fee). The limited access category designated journals that provided free access to some but not all of their content (beyond having a few selected articles available for free download or a free sample issue available on most publishers' Web sites), or provided free access in developing countries. The no or minimal open access category was applied to journals that required a subscription or pay-per-use fee for all or almost all of their content. Journals that had an open-choice option and/or an archiving policy but provided no other types of open access were coded in the no or minimal open access category. Although a limitation of our analyses is that we did not calculate interrater reliability estimates, the three authors reviewed and were in mutual agreement regarding the classification of the journals' access levels.

\section{Results}

Publisher type. From our list of 81 journals, 55 $(68 \%)$ were published by corporate publishers, 13 $(16 \%)$ by university presses, and 13 by professional organizations. A few large publishing houses accounted for the majority of titles in the corporate category. Taylor \& Francis published 35 titles, which constituted $43 \%$ of all journals in the sample. Sage, with six journals, distantly followed Taylor \& Francis, while the remaining eight corporate presses had three or fewer titles each. The university presses all published one title each. Professional organizations included NASW Press's four titles as well as others such as the Alliance for Children \& Families' Families in Society.

Subscription costs. Journals varied in their subscription schemes. Most had different individual and institutional subscription rates, the latter applying to universities and libraries. Journals also varied in their provision of print and online access to content, and the rates they charged for each type of access. Although a few titles were available only in print, most offered both print and online access, and some were published solely online. Most journals also offered paid access to single articles, and occasionally to single issues, usually via online download.

Table 1 summarizes average subscription costs by publisher and subscription type. Many journals had varied subscription rates for different types of access; for example, charging individuals a certain rate for online-only access and typically a slightly higher rate to receive the journal in print as well as online. Full subscription costs were used to calculate the averages, although some journals affiliated with professional organizations provide discounted or free individual subscriptions as a benefit to their members. The average subscription rates in Table 1 were calculated for journals that charge a subscription fee; that is, fully open access titles that do not charge individuals or institutions any fees to access content were not included.

The averages in Table 1 should be interpreted with caution given the large standard deviations indicating the very high degree of variability in pricing, both within publisher categories and across the sample as a whole. For example, institutional subscriptions for print and online access ranged from $\$ 146$ to $\$ 1,457$ in the corporate category, $\$ 88$ to $\$ 1,118$ in the university press category, and $\$ 90$ to $\$ 360$ in the professional organization category. For institutions, the single most expensive title based on 2011 pricing data was Child Abuse and Neglect: The International Journal, affiliated with the International Society for the Prevention of Child Abuse and Neglect and published by Elsevier, costing institutions $\$ 2,156$ annually for online access or a print version.

Although the small total sample size for each subscription scheme and the varying $n$ 's among the three publisher categories precluded meaningful statistical testing of differences in subscription rates by publisher type, some general trends can be observed in Table 1. Despite the small sample, journals published by universities generally offered lower individual subscription rates than those published by professional organizations or corporations. However, journals published by professional organizations had the lowest average institutional subscription costs. The highest institutional subscription costs, and the greatest price differential between individual and institutional subscriptions, were found in the corporate category. 
Table 1

Average Subscription Costs by Publisher and Subscription Type

\begin{tabular}{|c|c|c|c|c|c|c|c|c|c|c|c|c|}
\hline & \multicolumn{3}{|c|}{ Corporate } & \multicolumn{3}{|c|}{ University } & \multicolumn{3}{|c|}{$\begin{array}{l}\text { Professional } \\
\text { organization }\end{array}$} & \multicolumn{3}{|c|}{ Total sample } \\
\hline & $n$ & $\begin{array}{c}M \\
\text { (in \$) }\end{array}$ & $\begin{array}{c}S D \\
\text { (in \$) }\end{array}$ & $n$ & $\begin{array}{c}M \\
\text { (in \$) }\end{array}$ & $\begin{array}{l}S D \\
\text { (in \$) }\end{array}$ & $n$ & $\begin{array}{c}M \\
\text { (in \$) }\end{array}$ & $\begin{array}{l}S D \\
\text { (in \$) }\end{array}$ & $n$ & $\begin{array}{c}M \\
\text { (in \$) }\end{array}$ & $\begin{array}{l}S D \\
\text { (in \$) }\end{array}$ \\
\hline Individual, print only & 22 & 150 & 82 & 4 & 74 & 70 & 7 & 126 & 95 & 33 & 136 & 85 \\
\hline Individual, online only & 26 & 126 & 48 & 2 & 46 & 8 & 6 & 124 & 104 & 34 & 121 & 61 \\
\hline $\begin{array}{l}\text { Individual, print and } \\
\text { online }\end{array}$ & 29 & 129 & 52 & 4 & 70 & 27 & 6 & 153 & 105 & 39 & 39 & 63 \\
\hline $\begin{array}{l}\text { Institutional, print } \\
\text { only }\end{array}$ & 11 & 910 & 542 & 2 & 40 & 21 & 7 & 146 & 87 & 20 & 20 & 565 \\
\hline $\begin{array}{l}\text { Institutional, online } \\
\text { only }\end{array}$ & 47 & 673 & 394 & 2 & 506 & 602 & 6 & 183 & 80 & 55 & 55 & 405 \\
\hline $\begin{array}{l}\text { Institutional, print and } \\
\text { online }\end{array}$ & 48 & 674 & 344 & 5 & 380 & 441 & 9 & 182 & 93 & 62 & 62 & 372 \\
\hline $\begin{array}{l}\text { Price per single article } \\
\text { download }\end{array}$ & 50 & 32 & 4 & 4 & 14 & 9 & 8 & 26 & 15 & 62 & 62 & 8 \\
\hline
\end{tabular}

Note. Data reflect 2011 subscription prices.

Open-choice options, archiving policies, and access levels. Table 2 summarizes the use of openchoice options, archiving policies, and designated access levels for the journals in the sample by publisher type. Slightly more than half of the journals offered an open-choice option to authors, allowing authors to designate their article as open access in exchange for a fee. All of the journals offering this option were published by large corporate publishing houses, including Elsevier, Taylor \& Francis, Springer, and Wiley-Blackwell, with fees ranging from $\$ 2,950$ to $\$ 3,000$ per article.

Table 2

Open Choice Options, Archiving Policy, and Access Levels by Publisher Type

\begin{tabular}{|c|c|c|c|c|}
\hline & $\frac{\text { Corporate }}{n(\%)}$ & $\frac{\text { University }}{n(\%)}$ & $\begin{array}{l}\text { Professional } \\
\text { organization } \\
n(\%)\end{array}$ & $\frac{\text { Total sample }}{n(\%)}$ \\
\hline Has open choice option & $42(76)$ & $0(0)$ & $0(0)$ & $42(52)$ \\
\hline Has archiving policy & $50(91)$ & $7(54)$ & $9(69)$ & $66(81)$ \\
\hline \multicolumn{5}{|l|}{ Access level: } \\
\hline $\begin{array}{l}\text { No/minimal } \\
\text { open access }\end{array}$ & $34(62)$ & $4(31)$ & $9(69)$ & $47(58)$ \\
\hline $\begin{array}{l}\text { Limited open } \\
\text { Access }\end{array}$ & $19(35)$ & $3(23)$ & $1(8)$ & $23(28)$ \\
\hline $\begin{array}{l}\text { Full open } \\
\text { Access }\end{array}$ & $2(4)$ & $6(46)$ & $3(23)$ & $11(14)$ \\
\hline
\end{tabular}

A majority of journals (81\%) had written policies allowing authors some level of self-archiving. Although most of the corporate presses had established archiving policies that applied to all their titles, journals published by universities or professional organizations were less likely to have a written policy; some editors and publishers of these journals anecdotally reported dealing with author archiving requests on a case-by-case basis. In a few instances, mainly among fully open access journals, the publisher 
allowed copyright to remain with the author. However, far more common were archiving policies in which publishers retained copyright but authors were permitted to archive their work under certain conditions. For example, Taylor \& Francis' policy allows authors to archive the preprint version of their article in a personal or institutional repository immediately upon publication (or prior to publication if a journal's editorial policies allow this); authors may also archive the revised "post-print" version of an article after an embargo period of 18 months for social science journals, although they may not use the publisher's official PDF-file format of the article and must provide a link to the official electronic version of the article on Taylor \& Francis' website (Taylor \& Francis, n.d.). Of the journals that had archiving policies, 54 (82\%) imposed an embargo period before authors could selfarchive. The embargoes were 12, 18, or 24 months in length, depending on the publisher.

Access levels determined for each journal are summarized in Table 2. The majority of the sample $(58 \%)$ was classified as providing no or minimal open access, including about two-thirds of journals published by corporate presses or professional organizations, and one third of journals published by universities. It should be noted that some of the journals in this category - particularly those published by large corporations - did provide free access to a very small percentage of their content. For example, most of the titles published by Taylor \& Francis advertised free access to between one and 10 articles per journal, in addition to one free sample issue available on the journal's website. Typically, articles with free access are available on a rotating basis, and are free for a few months and then revert to paid access. As compared with journals published by universities or professional organizations, journals in the corporate category were more likely to offer partial access, primarily through providing free access to institutions in low-income countries through the WHO's HINARI project.

Full open access in social work journals. Eleven journals, representing a range of topics and specialty areas, were classified as fully open access journals. All met the definition of full open access by providing free online access to all current and archived journal content (it should be noted that one journal, the Journal of Social Work Values \& Ethics, reported switching to a new publisher in January 2013; it was not clear as of this writing if the journal would remain fully open access, though archives of past issues remained open on the journal's website). Titles, publishers, affiliations, founding years, publication schedules, and major indexing locations for these journals are listed in Table 3. In addition to original articles, journal content mirrored that of tra- ditional publication models, with the journals providing a range of content options such as editorials, book reviews, and research notes. Indexing of the fully open access journals in the main outlets appeared to be limited, as we located five titles indexed in the EBSCOhost network of databases, two in SWA, and one in PsycINFO (however, eight were indexed in Google Scholar). The only title with a JCR impact factor was the bilingual Romanian journal Review of Research and Social Intervention, with a 2011 impact factor of 1.186 (ranked eighth of 41 journals in JCR's social work category; JCR, 2012).

When we inquired about funding models, none of the journal editors reported charging authors any type of fee. Instead, editors reported relying upon a range of funding sources, including subsidies from universities or professional organizations, private donations, sale of print copies, and financial contributions from the editors themselves. The majority of editors also mentioned keeping costs low by volunteering their time and relying on others such as library staff to produce and publish the journals.

\section{Discussion}

Overall, our analyses indicate both barriers and facilitators to expanding access to social work literature. Access continues to be limited by high annual subscription costs, particularly for journals published by corporate presses. The majority of the 81 journals in our sample charged users for access to all or most of their content. Subscription rates present significant barriers for schools and libraries with shrinking budgets, as well as for individuals being asked to pay an average of $\$ 30$ for a single article download or $\$ 121$ for an annual online subscription.

Our analyses also indicate several mechanisms through which journals are facilitating access. First, even many of the journals classified as no or minimal open access had archiving policies enabling authors to self-archive their work, albeit after an embargo period. Another trend is the number of journals - 21 in our sample - offering access to institutions in developing countries through HINARI. Although representing a firm step toward expanding knowledge access on a global level, this approach can be unstable, as exemplified by the sudden withdrawal of free access to users in Bangladesh through HINARI by major commercial publishers in 2011 (in this instance, some access has since been restored following protests by scholars and practitioners; Kmietowicz, 2011). Further, nearly half of the journals provided an openchoice option allowing authors to make their article open access by paying a fee; however, we were unable to determine the extent to which this option is being used. 
Table 3

Fully Open Access Social Work Journals

\begin{tabular}{|c|c|c|c|}
\hline Title & Publisher/affiliation (if applicable) & Year founded & $\begin{array}{l}\text { Publication schedule: } \\
\text { Issues per year }\end{array}$ \\
\hline Advances in Social Work* 0 & Indiana University School of Social Work & $\begin{array}{c}2000 \\
\text { (OA since 2008) }\end{array}$ & 2 issues \\
\hline Critical Social Work & $\begin{array}{l}\text { University of Windsor School of Social } \\
\text { Work }\end{array}$ & 2000 & $\begin{array}{l}\text { Rolling; } \\
1-3 \text { issues }\end{array}$ \\
\hline $\begin{array}{l}\text { Currents: Scholarship in the } \\
\text { Human Services }\end{array}$ & $\begin{array}{l}\text { University of Calgary Press/University of } \\
\text { Calgary Faculty of Social Work }\end{array}$ & 2002 & $\begin{array}{l}\text { Rolling; } \\
1-2 \text { issues }\end{array}$ \\
\hline $\begin{array}{l}\text { Irish Journal of Applied Social } \\
\text { Studies }^{\circ}\end{array}$ & Social Care Ireland & $\begin{array}{c}1998 \\
\text { (OA since 2009) }\end{array}$ & $\begin{array}{l}\text { Rolling; } \\
1-2 \text { issues }\end{array}$ \\
\hline $\begin{array}{l}\text { Journal of Comparative Social } \\
\text { Work }\end{array}$ & University of Nordland & 2006 & 2 issues \\
\hline $\begin{array}{l}\text { Journal of Indigenous Social } \\
\text { Development }\end{array}$ & $\begin{array}{l}\text { University of Hawaii-Manoa School of } \\
\text { Social Work }\end{array}$ & 2010 & $1-2$ issues \\
\hline $\begin{array}{l}\text { Journal of Social Research \& } \\
\text { Policy }\end{array}$ & University of Oradea & 2010 & 2 issues \\
\hline $\begin{array}{l}\text { Journal of Social Work Values } \\
\text { \& Ethics* } 0\end{array}$ & White Hat Communications & 2004 & $2-3$ issues \\
\hline $\begin{array}{l}\text { Journal of the Society for Social } \\
\text { Work and Research } \diamond^{\circ}\end{array}$ & Society for Social Work and Research & 2010 & $\begin{array}{l}\text { Rolling; } \\
\text { 3-4 issues }\end{array}$ \\
\hline $\begin{array}{l}\text { Review of Research and Social } \\
\text { Intervention }{ }^{0}\end{array}$ & $\begin{array}{l}\text { Lumen Publishing House/Alexandru loan } \\
\text { Cuza University and Holt Romania } \\
\text { Foundation }\end{array}$ & $\begin{array}{c}2003 \\
\text { (OA since 2008) }\end{array}$ & 4 issues \\
\hline Social Work \& Society & Social Work \& Society Network & 2003 & $\begin{array}{l}\text { Rolling; } \\
1-2 \text { issues }\end{array}$ \\
\hline
\end{tabular}

OA = open access *Indexed in Social Work Abstracts

Although fully open-access social work journals are relatively few in number, they represent a gold standard in terms of access, and the 11 in our sample have survived thus far without transferring publishing costs to authors through fees. The oldest of the titles became fully open access in 2000 and several were founded within the past few years, suggesting that full open access is a growing movement in social work journal publishing. Further time and evaluation are needed to determine which funding strategies will be sustainable in the long-term for fully open access social work journals. It is not yet clear if the authorfee model embraced by many prominent fully open access journals in the sciences is realistic for social work, so alternatives may be needed. In addition, although the content of these journals is freely available to all, their limited current level of indexing in major portals such as EBSCOhost databases, PsycINFO, and SWA likely restricts the public's awareness of research disseminated through these outlets. Further, the fact that only one of the fully open access journals in our sample yet has an impact factor can certainly be a deterrent to potential authors.

\section{Implications for Research and Practice: Why Access Matters for Social Work}

Open access is an important issue for social work as a profession as well as an academic discipline. Here, we review implications for research and practice in three contexts: evidence-based practice, social work 
ethics, and broader efforts to improve social work publishing.

Open access in the context of evidence-based practice. Although anyone with Internet access can use websites such as the Cochrane Collaboration to locate summary information regarding treatment or practice approaches that others have deemed "evidence-based," the process of evidence-based practice requires a more individualized approach to knowledge-seeking. Gambrill (2007) has described evidence-based practice as a process centered on problem-based learning, in which practitioners learn to formulate questions about particular cases and search for and evaluate the relevant literature to answer these questions. This process is hampered when much of the literature is not widely accessible due to cost barriers. Websites that compile and provide free access to literature reviews can be useful resources for evidence-based practice, but reviews and manualized guidelines are generally inadequate to support the active processes for which Gambrill and other scholars advocate (Marsh, 2012; Rzepnicki et al., 2012).

Open access is particularly important when considering the needs of practitioners in less wealthy organizations, communities, and institutions in the United States and globally. In an era of fiscal contraction, neither governmental nor nonprofit agencies can devote expanded funding for information access through subscriptions or article downloads, even if they wish to promote the evidence-based practice paradigm among their staff. The limited level of knowledge access in low-resource settings has prompted some scholars to describe the situation as an "information famine" (Ahmed, 2007, p. 337). In addition, constrained access ultimately affects consumers and recipients of services, who might seek knowledge about the evidence base for available treatments and services in order to make informed choices, but lack the means to access such information. Truly embracing evidence-based practice requires resources for accessing, using, and sharing knowledge unconstrained by economic barriers.

Open access in the context of social work ethics. The NASW Code of Ethics states that,

Social workers should critically examine and keep current with emerging knowledge relevant to social work. Social workers should routinely review the professional literature and participate in continuing education relevant to social work practice and social work ethics.... Social workers should base practice on recognized knowledge, relevant to social work and social work ethics. (NASW, 2008)
The Code further states that "social workers strive to ensure access to needed information, services, and resources; equality of opportunity; and meaningful participation in decision making for all people" (NASW, 2008). It seems apparent that open access could contribute to this commitment. Further, the International Covenant on Economic, Social and Cultural Rights (United Nations, 1966) affirms "the right [of everyone] to enjoy the benefits of scientific progress and its applications."

Open access in the context of broader quality improvement efforts in social work publishing. The open access movement coincides with broader efforts to improve the quality, transparency, and timeliness of social work journals. These efforts are perhaps best encapsulated by the Miami Statement. At the annual meeting of the Society for Social Work and Research (SSWR) in 2005 in Miami, scholars met to discuss concerns about journal publishing practices, including long time lags between submission, acceptance decisions, and publication; lack of a rigorous review process at some journals; and copyediting mistakes resulting in errors in published articles. These concerns, and recommendations for addressing them, were published shortly thereafter in Social Work Research (Peer Review, 2005). The Miami Statement built on previous research that identified shortcomings in social work publication practices, such as Thyer and Myers' (2003) examination of variability in editorial review processes and Epstein's (2004) research on confirmatory response bias and overall review quality (Jenson, 2005).

To date, research on social work publication practices has not focused on access as a key dimension of knowledge dissemination. Although access was not a main facet of the Miami Statement, the San Antonio Response follow-up statement (Holden et al., 2008) incorporated recommendations to increase access, such as archiving and publication in open access journals, and ultimately urged stakeholders to "consider ways in which they can increase the free flow of scholarly communication" (p. 69). We believe that increasing access to content should be a priority for social work serials publishing concurrent with the other recommendations identified in the Miami Statement and San Antonio Response.

Publications such as the Journal of the Society for Social Work and Research, founded in part as a response to the Miami Statement, exemplify how journals can provide open access while ensuring a timely and high-quality editorial review process. The journal is published on a rolling basis as articles are reviewed, accepted, and finalized, which enables it to achieve a rapid turnaround time (typically less than 8 
weeks between submission and publication) without sacrificing rigor in the review process (SSWR, 2011). Although not an elixir for healing all that ails social work publishing, open access is compatible with both the spirit and the mechanisms suggested in the Miami Statement and San Antonio Response to advance the social work publishing enterprise as a whole to a higher standard of value, timeliness, and availability.

\section{Toward Open Access}

Expansion of access to essential information in social work involves potential contributions from the scholars, researchers, and practitioners who generate and transform knowledge; from the universities and organizations where much of that knowledge emerges; and from those who publish it. Many of the suggestions that follow have been developed by SPARC and the Association of Research Libraries; all have been implemented to a considerable degree across multiple disciplines, although as our data show, only to a limited extent within social work (SPARC, 2012c).

Authors, practitioners, and scholars. Although it might appear that scholars and practitioners have little power in moving toward greater open access, this has not proven to be the case in disciplines that have embraced open access practices. In such disciplines, as discussed earlier, fully open access publications can be among the most prestigious. Achieving this status depended primarily on the decisions of authors, particularly senior scholars, who can have significant impact on the expansion of access by privileging fully open access outlets as first choices (Create Change, 2012). When journals offer an open-choice option and finances allow, making that choice clearly expands access to published work. Supporting the development of and using institutional repositories also supports access. In addition, individuals can alter publication agreements or use an author addendum to retain all or some of their copyright rights to retain a greater ability to share and distribute their scholarship. Standardized forms for this purpose are readily available (SPARC, 2012d).

University faculties can move at least incrementally toward the Harvard Open Access Compact model (which a number of other universities have now adopted), establishing a policy that automatically requires a copyright license for the deposit of faculty members' scholarly products in the institution's digital repository, with some waivers allowed. Those who sit on grant review or promotion and tenure committees can insist that scholarship is evaluated based on quality, rather than the newness of publication outlets, and in some cases may privilege fully open-access outlets that meet quality requirements. For example, the Faculty Senate at Virginia Commonwealth University
(2010) approved a statement indicating that its promotion and tenure committees "should recognize that publication and editorial effort in open access, peerreviewed journals or re-publication of peer-reviewed articles in an open access repository offers added value and greater public good than scholarship made only available in expensive journal publications" (para. 3). In another example, Florida State University established a policy that open-access publications be reviewed according to the journal's standards for review and acceptance, rather than based on the prestige of the journal (Florida State University Libraries, 2012). A quick search on the Web discovered that many major universities are discussing ways to support attention to open access publication in promotion and tenure processes (see also Modern Language Association, 2012).

Equally important, respected authors can volunteer to serve on the editorial boards of fully open access journals and to be of service in other ways, including volunteering some labor for planning and development work. Further possibilities, arranged by level of intensity, include advocating for greater open access for journals for which they serve on editorial boards; advocating for open access after brief embargo periods for journals published by professional societies; and declining to review for expensive closed-access journals. Other simple steps for supporting expanded access include reading open access journals, sharing articles with colleagues, and using open access journal articles in course assignments.

Universities. A number of steps universities can take have already been mentioned, including establishing, publicizing, and incentivizing the use of institutional repositories, and establishing campuswide open access policies including, but not limited, to automatic deposit of faculty publications in those repositories (SPARC, 2012e; see also University of Kansas, 2012). University libraries are particularly valuable partners in such efforts, not only in establishing and publicizing repositories, but also by ensuring that a wide range of open access journals are included in library catalogs and by sharing information about open access and author options across campuses. In addition, university libraries can sponsor and offer technical support for journals with faculty on the editorial boards, using open-source systems such as Open Journal Systems, developed by the Public Knowledge Project. One of the most important contributions being made by contemporary library and information sciences, university libraries, the Association of Research Libraries, and SPARC is the development of secure, distributed digital archiving systems (see, for example, extensive recent work published in The Library Quarterly, or the International Journal of 
Digital Curation -itself an open access journal). Such systems ensure the preservation of open access publications, even in the event that those journals cease publication. Preservation to ensure long-term, uninterrupted access to intellectual content has of course always been a core library function.

Publishers. Publishers bring value to the journal process, including coordination of the review process, subscription management, production, and marketing services (although as printed editions are becoming less important there is less need for production and fulfillment services, and open access eliminates the need for subscription management). Driven in part by government mandates and in part by accelerating open access competition, publishers that want to remain in the field are necessarily developing new business models (Willinsky, 2009). Various forms of open choice and author fees are becoming increasingly standard. Keeping subscription prices reasonable and avoiding excessive bundling are likely to be helpful, as might instituting embargo periods of no more than 6 months, a standard already mandated by many Canadian and European science and medical research funders (Coalition of Open Access Policy Institutions, 2012). However, it should be noted that the potential impact of mandating shorter embargo periods remains a source of concern and controversy, particularly for publishers of humanities and social science journals. One study by a UK-based association of publishers reported that many libraries would be less likely to subscribe to journals in those fields if all scholarship were made publicly accessible after a maximum 6 month embargo (Association of Learned, Professional and Society Publishers and the Publishers Association, 2012).

Professional associations and scientific societies are a special case. Journal publication has historically been a significant source of revenue for such associations, both directly and as a benefit that encourages membership. In recent years, many organizations have begun contracting out production to commercial or university publishers, which has often, but not always, increased subscription costs. At the same time, some association publishers have embraced author rights to deposit in repositories as one means of supporting access, and embargoes as another (Willinsky, 2009).

\section{Conclusion}

As is the case for scholarship in general, for the professions the call for free access is not a question of convenience. Because much of social work practice involves core issues of human and community life, which are often embedded in a matrix of structural conditions, access to information important to strategic intervention is a critical question. Evidence-based practice and policy require ready access to the best available knowledge, freely and globally available to clients, practitioners, communities, advocacy groups, governments, nongovernmental organizations, and scholars. Efforts to expand such access are, in the opinion of the authors, consistent with the mission, purpose, and ethical standards of the social work profession.

\section{Authors Note}

Elizabeth A. Bowen is a doctoral candidate in the Jane Addams College of Social Work at the University of Illinois at Chicago.

Mark A. Mattaini is an associate professor in the Jane Addams College of Social Work at the University of Illinois at Chicago: mattaini@uic.edu

Sandra L. De Groote is an associate professor and scholarly communications librarian at the University of Illinois at Chicago: sgroote@uic.edu

Mark A. Mattaini is editor and Sandra De Groote is technical contact for the open access journal Behavior and Social Issues. This journal was not included in the sample for our analyses because it did not meet the inclusion criteria.

Correspondence regarding this article should be directed to Elizabeth Bowen, Jane Addams College of Social Work (MC 309), University of Illinois at Chicago, 1040 West Harrison Street, Chicago, Illinois 60607-7134 or via e-mail at ebowen2@uic.edu

\section{Acknowledgements}

The authors thank all of the journal editors and publishers who responded to our requests for information. In addition, we thank the anonymous reviewers of our original manuscript for their thorough and constructive feedback, which helped to improve the manuscript in many ways.

\section{References}

Ahmed, A. (2007). Open access towards bridging the digital divide-policies and strategies for developing countries. Information Technology for Development, 13(4), 337-361. doi:10.1002/itdj.20067

Association of Learned, Professional and Society Publishers and the Publishers Association. (2012, May). The potential effect of making journals free after a six month embargo. Retrieved from http://www.publishingresearch.net/documents/AL PSPPApotentialresultsofsixmonthembargofv.pdf

Association of Research Libraries. (2008). Graph 2: Monograph and serial expenditures in ARL libraries, 1986-2006. ARL statistics 2005-06. 


\section{OPEN ACCESS AND SOCIAL WORK}

Retrieved from

http://www.arl.org/bm doc/monser06.pdf

Beall, J. (2012). Beall's list of predatory, open access publishers. Retrieved from http://scholarlyoa.com/publishers/

Berger, R. (2010). EBP: Practitioners in search of evidence. Journal of Social Work, 10, 175-191. doi: $10.1177 / 1468017310363640$

Björk, B. C., Roosr, A., \& Lauri, M. (2008). Global annual volume of peer reviewed scholarly articles and the share available via different open access options. Proceedings ELPUB 2008 Conference on Electronic Publishing. Retrieved from http://elpub.scix.net/cgibin/works/Show?178_elpub2008

Bosch, S., Henderson, K., Klusendorf, H. (2011). Periodicals Price Survey 2011: Under pressure, times are changing. Retrieved from http://www.libraryjournal.com/lj/newslettersnews letterbucketacademicnewswire/890009440/periodicals_price_survey_2011_under.html.c $\mathrm{sp}$

Coalition of Open Access Policy Institutions. (2012, June 13). Letter of support for the Federal Research Public Access Act (FRPAA, H.R. 4004 and S. 2096). Retrieved from http://www.arl.org/sparc/bm doc/coapi-supportsfrpaa.pdf

Create Change. (2012). Making change work for you. Retrieved from http://www.createchange.org/change/index.shtml

Crow, R. (2009, September). Income models for open access: An overview of current practice.

Retrieved from the Scholarly Publishing \& Academic Resources Coalition website: http://www.arl.org/sparc/bm doc/incomemodels_ v1.pdf

Doyle, H., Gass, A., \& Kennison, R. (2004). Who pays for open access? PLoS Biology, 2(4), e105. doi:10.1371/journal.pbio.0020105

Epstein, W. M. (2004). Confirmational response bias and the quality of the editorial processes among American social work journals. Research on Social Work Practice, 14, 450-458. doi: $10.1177 / 1049731504265838$

Florida State University Libraries. (2012). Scholarly communications. Retrieved from http://guides.lib.fsu.edu/content.php?pid=228434 $\&$ sid $=1889920$

Gambrill, E. (2006). Evidence-based practice and policy: Choices ahead. Research on Social Work Practice, 16, 338-357. doi:10.1177/1049731505284205
Gambrill, E. (2007). Transparency as the route to evidence-informed professional education. Research on Social Work Practice, 17(5), 553560. doi:10.1177/1049731507300149

Hardisty, D. J., \& Haaga, D. F. (2008). Diffusion of treatment research: Does open access matter? Journal of Clinical Psychology, 64(7), 821-839. doi: $10.1002 /$ jclp.20492

Harvard University. (2010). Compact for open access publishing equity. Retrieved from http://osc.hul.harvard.edu/compact

Holden, G., Barker, K., Rosenberg, G., \& Cohen, J. (2012). Information for clinical social work practice: A potential solution. Clinical Social Work Journal, 40, 166-174. doi:10.1007/s10615011-0336-3

Holden, G., Thyer, B. A., Delva, J., Baer, J., Dulmus, C. N., \& Shanks, T. W. (2008). Suggestions to improve social work journal editorial and peerreview processes: The San Antonio response to the Miami Statement. Research on Social Work Practice, 18, 66-71. doi: $10.1177 / 1049731507303496$

Howard, M. O., McMillen, C. J., \& Pollio, D. E. (2003). Teaching evidence-based practice: Toward a new paradigm for social work education. Research on Social Work Practice, 13, 234-259. doi:10.1177/1049731502250404

Jenson, J. M. (2005). Structural factors and the quality of publication in social work journals. Social Work Research, 29, 67-71. doi:10.1093/swr/29.2.67

Kmietowicz, Z. (2011). Publishers withdraw 2500 journals from free access scheme in Bangladesh. British Medical Journal, 342(11), 196. doi:10.1136/bmj.d196

Laakso, M., \& Björk, B. C. (2012). Anatomy of open access publishing: A study of longitudinal development and internal structure. $B M C$ Medicine, 10, 124. doi:10.1186/1741-7015-10124

Laakso, M., Welling, P., Bukvova, H., Nyman, L., Björk, B. C., \& Hedlund, T. (2011). The development of open access publishing from 1993 to 2009. PLoS One, 6(6), e20961. doi:10.1371/journal.pone.0020961

LaPelle, N. R., Luckmann, R., Simpson, E. H., \& Martin, E. R. (2006). Identifying strategies to improve access to credible and relevant information for public health professionals: A qualitative study. BMC Public Health, 6, 89. doi:10.1186/1471-2458-6-89 
Lawrence, S. (2001). Free online availability substantially increases a paper's impact. Nature, 411 (6837), 521. doi:10.1038/35079151

Marsh, J. C. (2012). Learning by intervening: Examining the intersection of research and practice. In T. L. Rzepnicki, S. G. McCracken, \& H. E. Briggs (Eds.), From task-centered social work to evidence-based and integrative practice: Reflections on history and implementation (pp. 314). Chicago, IL: Lyceum Books.

Modern Language Association. (2012). Report of the MLA task force on evaluating scholarship for tenure and promotion. Retrieved from http://www.mla.org/tenure_promotion

National Association of Social Workers. (2008). Code of ethics. Retrieved from http://www.naswdc.org/pubs/code/code.asp

National Institutes of Health. (2008). National Institutes of Health public access. Retrieved from http://publicaccess.nih.gov/

Open Society Institute. (2002). Budapest open access initiative. Retrieved from http://www.soros.org/openaccess/read.shtml

Peer review and publication standards in social work journals: The Miami Statement. (2005). Social Work Research, 29(2), 119-121. doi:10.1093/swr/29.2.119

Peirson, L., Ciliska, D., Dobbins, M., \& Mowat, D. (2012). Building capacity for evidence informed decision making in public health: A case study of organizational change. BMC Public Health, 12, 137. doi:10.1186/1471-2458-12-137

Rzepnicki, T. L., McCracken, S. G., \& Briggs, H. E. (Eds.). (2012). From task-centered social work to evidence-based and integrative practice:

Reflections on history and implementation. Chicago, IL: Lyceum Books.

Scherlen, A., \& Robinson, M. (2008). Open access to criminal justice scholarship: A matter of social justice. Journal of Criminal Justice Education, 19(1), 54-74. doi:10.1080/10511250801892961

Scholarly Publishing \& Academic Resources Coalition. (2012a). Open access funds in action. Retrieved from http://www.arl.org/sparc/bm doc/oa-funds-inaction-attachment.pdf

Scholarly Publishing \& Academic Resources Coalition (2012b). Coalition of open access policy institutions. Retrieved from http://www.arl.org/sparc/about/COAPI/index.sht $\mathrm{ml}$
Scholarly Publishing \& Academic Resources Coalition (2012c). Publications. http://www.arl.org/sparc/publications/index.shtml

Scholarly Publishing \& Academic Resources Coalition. (2012d). Author rights: Using the SPARC Author Addendum to secure your rights as the author of a journal article. Retrieved from http://www.arl.org/sparc/author/addendum.shtml

Scholarly Publishing \& Academic Resources Coalition. (2012e). Campus open access policies. Retrieved from http://www.arl.org/sparc/advocacy/campus/

Society for Social Work and Research. (2011). JSSWR celebrates second year of publication. SSWR News, 18(1), 8-11. Retrieved from http://www.sswr.org/2011\%20SSWR\%20News\% 20Final.pdf

Solomon, D. (2008). Developing open access journals: A practical guide. Oxford, UK: Chandos. doi:10.1533/9781780632155

Taylor \& Francis. (n.d.). Schedule of author rights. Retrieved from http://www.tandf.co.uk/journals/pdf/copyrightauthor-rights.pdf

Thomson Reuters Journal Citation Reports. (2012). 2011 Journal Citation Reports ${ }^{\circledR}$. Retrieved from http://wokinfo.com/products_tools/analytical/jcr/

Thyer, B. A. (2008). The quest for evidence-based practice? We are all positivists! Research on Social Work Practice, 18, 339-345. doi: $10.1177 / 1049731507313998$

Thyer, B. A., \& Myers, L. L. (2003). An empirical evaluation of the editorial practices of social work journals. Journal of Social Work Education, 39(1), 125-140. Retrieved from http://www.jstor.org/stable/23043635

United Nations. (1966). International covenant on economic, social and cultural rights. New York, NY: Author. Retrieved from http://www2.ohchr.org/english/law/cescr.htm

University of California Berkeley. (2012). Selective list of open access and paid access fees. Retrieved from http://www.lib.berkeley.edu/scholarlycommunicat ion/oa_fees.html

University of Kansas. (2012). Open access at KU. Retrieved from http://www.lib.ku.edu/ openaccess/

Virginia Commonwealth University Faculty Senate. (2010). VCU Faculty Senate passes resolution on open access publishing. Retrieved from http://www.facultysenate.vcu.edu/tag/openaccess-scholarship-promotion-and-tenure/ 


\section{OPEN ACCESS AND SOCIAL WORK}

Willinsky, J. (2006). The access principle: The case for open access to research and scholarship. Boston, MA: MIT Press. Retrieved from http://mitpress.mit.edu/sites/default/files/titles/con tent/9780262512664_Download_the_full_text.pdf

Willinsky, J. (2009). The stratified economics of open access. Economic Analysis and Policy, 39(1), 5370. Retrieved from http://www.eapjournal.com.au/download.php?file $=691$

World Health Organization. (2012, January). HINARI infosheet. Retrieved from http://www.who.int/hinari/HINARI_INFOSHEE T_ENGLISH_2012.pdf
Yu, L. (2006). Understanding information inequality: Making sense of the literature of the information and digital divides. Journal of Librarianship and Information Science, 38(4), 229-252. doi: $10.1177 / 0961000606070600$

Submitted: August 17, 2012 Revision submitted: January 4, 2013 Revision submitted: February 12, 2013

Accepted: February 12, 2013

Published online: March 4, 2013 


\section{Appendix A \\ Social Work-Related Journals Included in Analyses}

Administration in Social Work

Advances in Social Work

Affilia--Journal of Women and Social Work

Asia Pacific Journal of Social Work and

Development

Australian Social Work

British Journal of Social Work

Canadian Social Work Review

Child \& Adolescent Social Work Journal

Child \& Family Social Work

Child \& Youth Services

Child Abuse \& Neglect: The International Journal

Child Abuse Review

Child Maltreatment

Child Welfare

Children and Schools

Children and Youth Services Review

China Journal of Social Work

Clinical Social Work Journal

Critical Social Work

Currents: Scholarship in the Human Services

Ethics and Social Welfare

European Journal of Social Work

Families in Society: The Journal of

Contemporary Social Services

Health \& Social Work

Indian Journal of Social Work

International Journal of Social Welfare

International Social Work

Irish Journal of Applied Social Studies

Journal of Baccalaureate Social Work

Journal of Community Practice

Journal of Comparative Social Welfare
Journal of Comparative Social Work

Journal of Ethnic \& Cultural Diversity in Social Work

Journal of Evidence-Based Social Work

Journal of Family Social Work

Journal of Forensic Social Work

Journal of Gay and Lesbian Social Services

Journal of Gerontological Social Work

Journal of HIV/AIDS \& Social Services

Journal of Human Behavior in the Social

Environment

Journal of Indigenous Social Development

Journal of Policy Practice

Journal of Practice Teaching and Learning:

Social Work, Health, Nursing

Journal of Progressive Human Services

Journal of Public Child Welfare

Journal of Religion and Spirituality in Social Work: Social Thought

Journal of Social Research \& Policy

Journal of Social Service Research

Journal of Social Work

Journal of Social Work in Disability \&

Rehabilitation

Journal of Social Work Education

Journal of Social Work in End-of-Life \&

Palliative Care

Journal of Social Work Practice

Journal of Social Work Practice in the

Addictions

Journal of Social Work Values and Ethics

Journal of the Society for Social Work and Research

Journal of Sociology \& Social Welfare

Journal of Teaching in Social Work
Practice: Social Work in Action

Professional Development: The International Journal of Continuing Social Work Education

Psychoanalytic Social Work

Qualitative Social Work: Research and Practice

Reflections: Narratives of Professional Helping

Research on Social Work Practice

Review of Research and Social Intervention

School Social Work Journal

Smith College Studies in Social Work

Social Service Review

Social Work

Social Work \& Society

Social Work and Christianity: An International Journal

Social Work Education: The International Journal

Social Work Forum

Social Work with Groups

Social Work in Health Care

Social Work in Mental Health

Social Work in Public Health

Social Work Research

Social Work Review

Social Work and Social Sciences Review

The Social Work Practitioner-Researcher 